\title{
Medical students' knowledge of the human papillomavirus (HPV), cervical cancer, and HPV vaccination
}

\author{
Conhecimento dos alunos de medicina sobre papilomavírus humano (HPV), câncer cervical e vacinação \\ contra HPV
}

\author{
Miriam da Silva Wanderley' (D) miriamsw@unb.br \\ Dejano Tavares Sobral' ${ }^{1}$ (D) $d$ tsobral@gmail.com \\ Ceres Nunes Resende' ${ }^{1}$ (D) ceres.resende@yahoo.com \\ Lívia de Azevedo Levino' ${ }^{1}$ (B) livia.levino@gmail.com \\ Luísa de Assis Marques ${ }^{1}$ (D) luamarques102@gmail.com \\ Mateus Silva Feijó1 (1) teusfeijo@gmail.com \\ Nathália Regina Cardoso Aragão' (1) nathaliacaragao@hotmail.com
}

\begin{abstract}
Introduction: Medical students still have many doubts regarding HPV (Human papillomavirus) and the vaccine against this virus.

Objective: The study aimed to assess the University of Brasilia medical students' grasp of knowledge about HPV, its relationship with cancer, and the vaccine against the virus.

Methods: A cross-sectional study was undertaken by applying a survey questionnaire on the topics. The evaluation involved 379 respondents, $72.7 \%$ of the 521 students from the $1^{\text {st }}$ to the $6^{\text {th }}$ years enrolled in the second semester of 2017 . The statistical analyses included differences between means and proportions, effect size measures, and the correlation between the identified indicators. The study was approved by the Ethics Committee in Research on Human Beings of the School of Medicine $(1,989,835)$.

Results: The 50-item knowledge score increased progressively with the year attended by the medical students $(r=.706, p<.001)$, and was higher among the sexually-active compared to celibate participants $(t=3.26, d f=275, p=0.001, d=0.37)$, as well as among participants with higher family income compared to those with lower family income $(t=2.91, d f=366, p=.004, d=.35)$. No significant score differences emerged between participants grouped by gender, sexual behavior, or HPV vaccination status. Furthermore, gender (female; $\mathrm{OR}=6.5, \mathrm{p}<.001)$, age range $(<24$ years; $\mathrm{OR}=3.3, \mathrm{p}=.001$ ), sexuality (active; $\mathrm{OR}=2.7, \mathrm{p}=.002$ ), but not overall knowledge were predictors of the wish to be vaccinated among the 297 unvaccinated students.

Conclusion: The study revealed a strong correlation of medical students' HPV-related knowledge with medical school year and significantly higher scores among sexually active and higher-income respondents, but there were no essential differences between males and females or between vaccinated and unvaccinated students. Among the latter participants, gender, age, and sexuality, but not knowledge, were the best predictors of the wish to be vaccinated. The findings suggest the need for improving HPV screening and vaccination programs and educational strategies regarding HPV-related diseases.
\end{abstract}

Keywords: Medical Students; Knowledge; Human Papillomavirus; Vaccination; Sexual Behavior.

\section{RESUMO}

Introdução: Há ainda, entre os estudantes de Medicina, muitas dúvidas com relação ao papilomavírus humano (HPV) e à vacina contra esse vírus.

Objetivo: Este estudo teve como objetivo avaliar a compreensão dos estudantes de Medicina da Universidade de Brasília acerca do HPV, da sua relação com o câncer e da vacina contra o vírus.

Método: Foi realizado um estudo transversal por meio da aplicação de um questionário teste sobre os temas. A avaliação envolveu 379 respondentes, o que representava $72,7 \%$ dos 521 alunos do primeiro ao sexto ano matriculados no segundo semestre de 2017. As análises estatísticas incluíram diferenças entre médias e proporções, medidas de tamanho de efeito e a correlação entre os indicadores identificados. O estudo foi aprovado pelo Comitê de Ética em Pesquisa em Seres Humanos da Faculdade de Medicina $(1,989,835)$.

Resultado: A pontuação de conhecimento de 50 itens aumentou progressivamente com o ano do curso médico $(r=0,706, p<0,001)$ e foi maior entre os participantes sexualmente ativos em comparação com os celibatários $(t=3,26, d f=275, p=0,001, d=0,37)$, e entre os participantes com renda familiar mais alta em comparação com aqueles com renda mais baixa $(t=2,91, d f=366, p=0,004, d=0,35)$. Nenhuma diferença significativa de pontuação foi observada entre os participantes agrupados por gênero, comportamento sexual ou estado de vacinação contra o HPV. Além disso, sexo (feminino; OR = $6,5, p<0,001$ ), faixa etária ( $<24$ anos; $O R=3,3, p=0,001$ ) e sexualidade (ativo; $O R=2,7, p=0,002$ ), mas não o conhecimento geral, foram preditores do desejo de vacinação entre 297 alunos não vacinados.

Conclusão: O estudo revelou uma forte correlação entre o conhecimento relacionado ao HPV dos estudantes de Medicina e o ano de estudo, e pontuações significativamente mais altas entre os respondentes sexualmente ativos e de renda superior, mas não houve nenhuma diferença essencial entre homens e mulheres ou entre alunos vacinados e não vacinados. Entre estes últimos, gênero, idade, sexualidade, e não o conhecimento foram os melhores preditores do desejo de vacinação. Os achados sugerem a necessidade de aperfeiçoamento em programas de triagem e vacinação para HPV e nas estratégias educacionais referentes às doenças relacionadas ao vírus.

Palavras-chave: Estudantes de Medicina; Conhecimento; Papilomavírus Humano; Vacinação; Comportamento Sexual.

1 Universidade de Brasília, Brasília, Distrito Federal, Brazil.

Chief Editor: Rosiane Viana Zuza Diniz.

| Associate Editor: Pedro Tadao Hamamoto Filho.

Received on 03/03/21; Accepted on 06/06/21. | Evaluated by double blind review process. 


\section{INTRODUCTION}

Cervical cancer is a public health problem, since it is the fourth most common type of cancer and the fourth cause of death due to the occurrence of neoplasia in the female population worldwide, the vast majority occurring in developing countries $^{1}$. As an example, 16,590 new cases of cervical cancer per year are expected in 2020-22 in Brazil, according to data from National Cancer Institute, with an estimated average risk of 15.43 new cases per 100,000 women².

Among the known risk factors for developing cervical cancer, high-risk Human Papillomavirus (HPV) infection ranks a prominent place ${ }^{3,4}$. Experts estimate that most sexually active men and women will have contact with the virus at some point in their lives. However, spontaneous regression of the infection occurs in more than $80 \%$ of the cases ${ }^{5}$. Infection persistence is necessary for the onset of neoplasia and it has an estimated 8599\% prevalence in cervical cancer cases ${ }^{6}$.

The Brazilian Health System introduced the HPV immunization program in 2014. Currently, in addition to other specific indications, the quadrivalent HPV vaccine is available in the Unified Health System (SUS) for females aged nine to 14 years and males aged 11 to 14 years in a two-dose schedule with a 6-month interval ${ }^{7}$. The strong correlation between oncogenic HPV infection and cervical cancer makes vaccination an essential public health prevention tool ${ }^{8}$. However, although clinical trials established the vaccine's safety and efficacy ${ }^{9}$, the adherence to vaccination falls short of conventional standards. In 2017, the cumulative vaccination coverage of the HPV vaccine in Brazilian girls aged nine to 14 years was $82.6 \%$ for the first dose and $52.8 \%$ for the second dose. Among boys aged 12 and 13 , only $43.8 \%$ of them had received the first dose ${ }^{7}$.

Solid knowledge and a positive attitude towards the vaccine among medical students indicate a favorable outlook for their future actions as health service providers in adhering to screening and vaccination programs ${ }^{10}$. For example, in the United States, Afonso et al. ${ }^{11}$, using a 15-item survey, highlighted that fully vaccinated compared to non-vaccinated respondents had a better understanding and more positive attitudes. However, in Scotland, McCusker et al. ${ }^{12}$ revealed the lack of knowledge of first-year students about the extent of protection against cervical cancer provided by the vaccine, and in China, Wen et al. ${ }^{13}$ indicated poor knowledge of HPV and HPV vaccination among medical students.

Therefore, the study aimed to assess the medical students' grasp of knowledge related to HPV, its relationship with cervical cancer, and the vaccine against the virus according to their profiles, level of study, and vaccination status. It was assumed that a significant relationship would be found between the students' knowledge and their level of study and demographic profiles.

\section{METHODS}

\section{Participants}

In a cross-sectional study, students attending from the first to the sixth years of medical school at the University of Brasilia answered a survey devised as a test questionnaire. The survey test included questions about cervical cancer, HPV, and the vaccine against HPV, with possible responses including, Yes, No, and I Don't Know. The development of the instrument benefited extensively from published examples in the literature ${ }^{8,14-16}$. The Ethics Committee in Research on Human Beings of the School of Medicine approved the study $(1,989,835)$.

The eligibility criteria comprised attendance in the second semester of 2017 by students aged at least 18 years old from each period (semester) of the undergraduate medical school. As a rule, students were contacted during class time. As reported elsewhere, 392 students returned the survey tool and the signed consent form, but 13 cases were excluded from the study (six because the respondents omitted information about HPV vaccination and seven because they were younger than 18 years old ${ }^{17}$. Therefore, the analyses included the questionnaires from 379 students, $72.7 \%$ of 521 students enrolled in the second half of 2017. Therefore, the estimated sample size for a satisfactory response rate ( $95 \%$ confidence level, $3 \%$ interval) comprised 350 students.

\section{Procedures}

We grouped the participants according to gender, monthly family income, sexuality profile, vaccination status, and year at medical school. The family income, established according to the number of minimum wages earned per month upheld two groups: a higher-income ( $\geq$ five minimum wages per month) and a lower-income (< five minimum wages per month) group. Regarding the vaccination status, three groups were identified: one of vaccinated participants, a second comprising those who were not vaccinated but who wished the immunization and the third included the students who did not receive nor wanted the vaccine. As for the sexuality, celibates constituted one group and sexually-active participants the other. Finally, the study level separated students attending years 1 to 4 from years 5 to 6 (which includes the internship). This last criterion included students before and after approval in Gynecology and Obstetrics courses (held in the $8^{\text {th }}$ semester of the medical program).

A preliminary review of the responses to 57 knowledge items of the questionnaire excluded seven questions with a problematic discrimination index and item-total score correlation. For the remaining 50 questions, the reliability analysis showed acceptable internal consistency (Cronbach's alpha $=0.87$ ), even if a factor analysis detected multiple components in the students 
responses. Thus, a sum of correct answers was calculated for that set of items. Henceforth, the resulting total score, expressed as a percentage, was named the K-test score.

\section{Statistical Analysis}

In addition to means, frequencies, and proportions, the statistical analyses included t-tests for differences, Pearson's correlations, analyses of contingency and one-way ANOVA, all for K-test scores between the student groups. Effect sizes and confidence intervals $(\mathrm{Cl})$ were calculated, and $\mathrm{p}<0.05$ (two-tailed) was adopted for statistical significance. The SPSS software, version 17 , was used in the statistical analysis.

\section{RESULTS}

The mean age of the 379 participants was $21.8 \pm 3.1$ years and, among them, $82(21.6 \%)$ were aged 24 or older. Of the total, 218 (57.5\%) were males, and among 368 respondents, 279 (75.8\%) reported a monthly family income equal to or greater than five minimum wages. As for the sexuality profile, of the 372 respondents (who informed about recent sexual partners), 218 (58.6\%) used barrier contraceptive methods, 97 (26.1\%) declared themselves to be celibates, 93 (25.0\%) reported two or more partners, and 44 (11.8\%) admitted sexual initiation before 16 years of age.

Regarding the participants' HPV-vaccination status, 80 (21.1\%) reported being vaccinated, while 215 (56.7\%) had not received the vaccine but wished to, and 84 (22.2\%) had neither received it nor wanted to. However, the rates of vaccination were significantly different between males (9.2\%) and females (37.3\%); the odds ratio for female immunization was 5.88 (95\% $\mathrm{Cl} 3.36,10.29)$; Fisher's exact test $<0.0001$.

The K-test average score for the 379 participants was $60.6 \%$ $(S D=15.4 \%)$. The correlation between the student's score and the year at the medical school was strong $(r=.706, p<0.001)$. In addition, students attending years 5 to 6 had a much higher score than those attending years 1 to $4(t=19.0, d f=262.6, p<0.0001)$. Figure 1 shows the upward trend of the K-test results for students from year 1 to year 6 and highlights the increase in the growth rate from year 4 to year 5 , in parallel to K-test topics' formal learning in the $8^{\text {th }}$ semester of the Gynecology-Obstetrics courses.

Sexually-active students had higher K-test scores than celibate students $(t=3.26, d f=275, p=0.001$ ). Likewise, students who reported higher family income had higher scores than those who reported lower income $(t=2.91$, $d f=366, p=$ 0.004). On the other hand, there was no significant difference between male and female students regarding the K-test scores $(t=0.47, d f=377, p=0.638)$. The data depicted in Table 1 show the much larger effect size (Cohen's d) of the study level when compared to the other conditions.
Using one-way ANOVA procedures, no significant differences in K-test scores were found among respondents, grouped according to sexual behavior $(F=0.54$, df $=2 ; 367$, $p=0.593$ ). Similarly, no significant differences emerged in $K$ test scores between participants grouped according to HPV vaccination status $(F=2.85, d f=2 ; 376, p=0.059)$. Nevertheless, the scores increased according to adherence status: from 58.3 (not vaccinated, nor willing to), to 60.3 (not vaccinated, but willing to) to 64.0 (vaccinated).

According to the students' level of study, a distinctive upward trend in the percentage of correct answers was observed for most K-test items. Table 2 shows the association (for 13 selected items) between each item answer (correct or incorrect) and the level of study ( $1^{\text {st }}$ to $4^{\text {th }}$ year vs. $5^{\text {th }}$ to $6^{\text {th }}$ year). Again, significant associations appeared for both underperforming and high-performing items. However, in contrast to informationbased responses, responses to attitude-related questions (e.g., vaccination and multiple sexual partners) were not associated with the study level.

Only three of the 50 K-test items $(36,49$, and 50) showed a significant association with HPV vaccine acceptance among the 297 unvaccinated students. Table 3 shows the association between each response item (correct or incorrect) and acceptance of vaccination (unwilling vs. wishing). However, in an unplanned binary logistic regression analysis, four variables were significant predictors of vaccine desirability: gender (female; $\mathrm{OR}=6.5, \mathrm{p}<0.001)$, age group ( $<24$ years; $\mathrm{OR}=3.3, \mathrm{p}=0.001)$, sexuality (active; $O R=2.7, p=0.002$ ) and item 36 (incorrect; $O R$ $=2.0, p=0.029$ ). In the regression model summary, Nagelkerke $\mathrm{R}$ Square was equal to 0.227 (meaning that those four items represent $22.7 \%$ of the variability in HPV vaccination desire).

Figure 1. The first-to-sixth year medical students' knowledge of HPV-related topics (K-test)

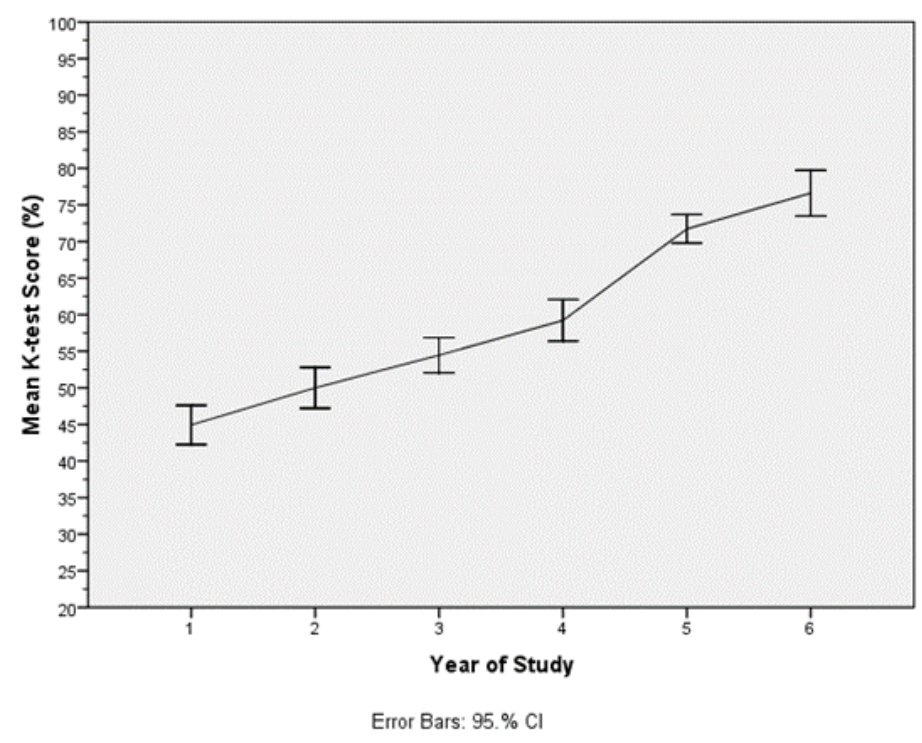


Table 1. Differences (by decreasing effect size) in K-test scores between medical students grouped according to their level of studies, sexuality, monthly family income, and gender.

\begin{tabular}{|c|c|c|c|c|c|}
\hline Students' Conditions & Groups & $\mathbf{N}$ & $\begin{array}{c}\text { K-test scores } \\
\text { Mean (SD) }\end{array}$ & Difference $(95 \% \mathrm{Cl})$ & Cohen's d \\
\hline \multirow{2}{*}{ Level of study } & Years 5-6 & 108 & $76.6(9.3)$ & \multirow{2}{*}{$22.3(20.1,24.7)$} & \multirow{2}{*}{1.91} \\
\hline & Years 1-4 & 271 & $54.3(12.5)$ & & \\
\hline \multirow{2}{*}{ Sexuality } & Sexually Active & 267 & $62.2(14.7)$ & \multirow{2}{*}{$5.6(2.2,9.0)$} & \multirow{2}{*}{0.37} \\
\hline & Celibate & 110 & $56.6(15.5)$ & & \\
\hline \multirow{2}{*}{$\begin{array}{l}\text { Monthly family } \\
\text { income }\end{array}$} & $>$ US\$300 & 279 & $62.0(15.3)$ & \multirow{2}{*}{$5.4(1.8,9.1)$} & \multirow{2}{*}{0.35} \\
\hline & $<$ US\$300 & 89 & $56.6(15.2)$ & & \\
\hline \multirow{2}{*}{ Gender } & Male & 218 & $60.3(15.6)$ & \multirow{2}{*}{$-0.08(-3.9,2.4)$} & \multirow{2}{*}{0.05} \\
\hline & Female & 161 & $61.1(15.2)$ & & \\
\hline
\end{tabular}

K-test: knowledge (\%) of items related to human papillomavirus and associated conditions.

$\mathrm{Cl}$ : confidence interval. Cohen's d: effect size.

Table 2. Measures of association (Odds Ratio) between the study levels and correct responses to survey items on the medical students' knowledge about HPV-related topics.

\begin{tabular}{|c|c|c|c|c|c|}
\hline \multirow{2}{*}{$\begin{array}{l}\text { Survey items (ordered by increasing } \\
\text { percentage of overall correct answers) }\end{array}$} & \multirow{2}{*}{$\begin{array}{l}\text { Correct/ Incorrect } \\
\text { Response }\end{array}$} & \multicolumn{2}{|c|}{ Study Levels } & \multirow{2}{*}{$\begin{array}{l}\text { Odds Ratio } \\
(95 \% \mathrm{Cl})\end{array}$} & \multirow{2}{*}{$\begin{array}{l}\text { Fisher's } \\
\text { Exact test }\end{array}$} \\
\hline & & Year 1-4 & Year 5-6 & & \\
\hline \multirow{2}{*}{ HPV is a cause of infertility } & C & 7 & 34 & \multirow{2}{*}{$17.2(7.3,40.5)$} & \multirow{2}{*}{$<0.0001$} \\
\hline & I & 263 & 74 & & \\
\hline \multirow{2}{*}{$\begin{array}{l}\text { The preventive Pap smear can detect HPV } \\
\text { infection }\end{array}$} & C & 16 & 32 & \multirow{2}{*}{$6.7(3.5,12.8)$} & \multirow{2}{*}{$<0.0001$} \\
\hline & I & 254 & 76 & & \\
\hline \multirow{2}{*}{ HPV causes genital herpes } & C & 68 & 77 & \multirow{2}{*}{$7.4(4.5,12.2)$} & \multirow{2}{*}{$<0.0001$} \\
\hline & I & 202 & 31 & & \\
\hline \multirow{2}{*}{ HPV vaccine is available to both boys and girls } & $\mathrm{C}$ & 95 & 90 & \multirow{2}{*}{$9.2(5.2,16.2)$} & \multirow{2}{*}{$<0.0001$} \\
\hline & I & 175 & 18 & & \\
\hline \multirow{2}{*}{$\begin{array}{l}\text { HPV can be transmitted by sitting on a } \\
\text { toilet seat }\end{array}$} & C & 109 & 95 & \multirow{2}{*}{$10.8(5.8,20.2)$} & \multirow{2}{*}{$<0.0001$} \\
\hline & I & 161 & 13 & & \\
\hline \multirow{2}{*}{ HPV may cause anal and oral cancers } & $\mathrm{C}$ & 151 & 85 & \multirow{2}{*}{$2.9(1.7,4.9)$} & \multirow{2}{*}{$<0.0001$} \\
\hline & 1 & 119 & 23 & & \\
\hline \multirow{2}{*}{ Early sex is a risk factor for cervical cancer } & $\mathrm{C}$ & 164 & 99 & \multirow{2}{*}{$7.2(3.5,14.8)$} & \multirow{2}{*}{$<0.0001$} \\
\hline & $\mathrm{I}$ & 107 & 9 & & \\
\hline \multirow{2}{*}{ HPV vaccination is inadequate for males } & C & 186 & 95 & \multirow{2}{*}{$3.3(1.7,6.2)$} & \multirow{2}{*}{0.0001} \\
\hline & 1 & 84 & 13 & & \\
\hline \multirow{2}{*}{ Most HPV infections are symptomatic } & C & 183 & 101 & \multirow{2}{*}{$6.9(3.1,15.4)$} & \multirow{2}{*}{$<0.0001$} \\
\hline & I & 87 & 7 & & \\
\hline HPV vaccination promotes sexual & C & 205 & 85 & $12(0720)$ & 05972 \\
\hline promiscuity & I & 66 & 23 & & \\
\hline The efficacy of HPV vaccination is higher & C & 210 & 101 & $41(1893)$ & $0 \cap 003$ \\
\hline before sexual initiation & I & 60 & 7 & 4.1 (1.8,9.3) & 0.0003 \\
\hline Multiple sexual partners are a risk factor for & C & 215 & 107 & 279 (38 804$)$ & $<00001$ \\
\hline cervical cancer & I & 56 & 1 & $27.9(0.0,204)$ & $<0.0001$ \\
\hline The HPV vaccine is available in the public & C & 246 & 108 & $10.5(14789)$ & 0.0047 \\
\hline health services & I & 24 & 1 & $10.5(1.4,18.9)$ & 0.0047 \\
\hline
\end{tabular}

HPV: human papillomavirus. C: correct. I: incorrect. Cl: confidence interval. 
Table 3. Measures of association (Odds Ratio) between medical students' responses to items about knowledge on HPV-related topics and their acceptance of the HPV vaccine

\begin{tabular}{lccccc}
\hline \multicolumn{1}{c}{ Survey Items (number) } & $\begin{array}{c}\text { Correct, Incorrect } \\
\text { Response }\end{array}$ & $\begin{array}{c}\text { Acceptance of Vaccine } \\
\text { Not Wishing }\end{array}$ & Wishing & $\begin{array}{c}\text { Odds Ratio } \\
(95 \% \text { CI) }\end{array}$ & $\begin{array}{c}\text { Fisher's Exact } \\
\text { Test }\end{array}$ \\
\hline $\begin{array}{l}\text { 49. The HPV vaccine is available in the } \\
\text { public health services }\end{array}$ & $\mathrm{C}$ & 73 & 205 & $3.1(1.3,7.6)$ \\
\hline $\begin{array}{l}\text { 50. The HPV vaccine is available to both } \\
\text { boys and girls }\end{array}$ & $\mathrm{I}$ & 11 & 10 & 110 & $1.8(1.1,3.0)$ \\
\hline $\begin{array}{l}\text { 36. Most HPV infections are } \\
\text { symptomatic }\end{array}$ & $\mathrm{I}$ & 31 & 105 & 0.0137 \\
\hline $\begin{array}{l}\text { 11. Multiple sexual partners are a risk } \\
\text { factor for cervical cancer }\end{array}$ & $\mathrm{C}$ & 55 & 167 & $1.8(1.1,3.2)$ \\
\hline
\end{tabular}

HPV: human papillomavirus. C: correct. I: incorrect. Cl: confidence interval.

Concerning some specific items, $81 \%$ of participants satisfactorily recognized various risk factors for cervical carcinoma, and only $3.7 \%$ were unaware of the Pap smear test. Also, 94.7\% knew that HPV could infect men and women, and more than $60 \%$ knew the causal association of HPV with various cancer sites. Furthermore, most of the students (73.6\%) knew about the protection against cervical cancer offered by the HPV vaccine, but $23.5 \%$ of the participants suspected that vaccination could increase sexual promiscuity. Besides, 93.7\% of students were aware of the availability of the HPV vaccine in public health services, but only $48.9 \%$ of them knew that the vaccine is available to both sexes.

\section{DISCUSSION}

As expected, a significant association emerged between the participants' knowledge of HPV-related topics (K-test score) and level of medical study, a finding similar to what was reported by other authors ${ }^{18-21}$. Notably, the increase in the K-test score growth rate between the fourth and fifth years was associated with the approval in the Ob-Gyn courses in the $8^{\text {th }}$ semester of the medical school. The robust odds ratios observed for 13 items in Table 2 corroborate the influence of that learning experience.

Also, significant differences in K-test scores emerged for the income and sexual activity groups. Regarding the family income, the means of correct answers were significantly lower in the lower-income group. Thus, income can be a potential influencer in terms of the students' access and incorporation/ understanding of available information. As for sexual activity, it is interesting to note that celibate students scored lower on the knowledge of HPV-related topics, perhaps because it was not their concern at that time. A recent study found no association between receiving the
HPV vaccine and sexual behavior, condom, and contraceptive method use $\mathrm{e}^{22}$.

No significant gender difference turned up in the K-test score, a finding similar to that reported by Liu et al. ${ }^{10}$. Notably, the HPV vaccination rate was significantly higher among women. However, the three-year delay in the inclusion of boys in the national HPV immunization program ${ }^{7}$ may partly explain the lower adherence to the vaccine by men. Additionally, the vaccination campaigns focused on cervical cancer prevention, not on penis, anal, and oropharynx cancer prevention ${ }^{21}$.

Several factors may explain the inconclusive differences in K-test scores concerning students' vaccination status. First, the K-test score is a global measure of declarative HPV-related knowledge, and vaccination seems to be associated with specific information. Second, the immunization timing preceded the appraisal of knowledge in this study, given the students' age profile. Third, we found evidence that personal advice (mostly parental) was a more powerful source of influence among those participants ${ }^{17}$. The finding that corroborates this line of reasoning was that only three information items were related to the acceptance (desire) of the HPV vaccine. Of course, health professionals' attitudes, the standard of public health information, and various individual, social, and cultural factors may better explain acceptance and adherence to vaccination.

Overall, the data from the present study showed that most students satisfactorily recognized the risk factors for cervical carcinoma; $94.7 \%$ knew that HPV could infect both sexes, and over $60 \%$ knew the association between HPV and several cancer sites. However, Deriemaeker et al. ${ }^{16}$ found that despite the high HPV vaccination rate in Belgium, $46 \%$ of medical students and $26 \%$ of students from other courses knew that HPV could cause cancer in the anogenital region (anus and penis). In another study, only $44 \%$ of the medical students 
surveyed at a university in India correctly answered that HPV could cause vulva, penis, oral and vaginal cancer ${ }^{23}$.

Additionally, surveys from six Chinese universities found that only $14.4 \%$ of medical students who answered a questionnaire believed that persistent HPV infection could cause cervical cancer, and $48.8 \%$ of them that vaccination could prevent cervical cancer ${ }^{8}$. In the present study, most participants (73.6\%) were aware of the protection against cervical cancer offered by the HPV vaccine.

Notably, almost a quarter of the participants admitted the influence of HPV vaccination on sexual promiscuity. This issue has been a concern of parents regarding girls' immunization, mainly about the risk of stimulating early sexual intercourse ${ }^{24}$. A study conducted in 2009 showed that, for those people, sexuality should be discussed before vaccination, since many believed that campaigns could increase risky sexual behavior ${ }^{25}$. However, a study carried out in England did not observe differences regarding sexual behavior between groups of vaccinated and non-vaccinated adolescents ${ }^{26}$. Also, a Scandinavian study found that the mean age at the first sexual intercourse was not significantly different between women who had been vaccinated against HPV before or after the onset of sexual activity and the number of sexual partners ${ }^{27}$.

The present study has limitations. Because of its crosssectional design, it not possible to establish a cause-effect relationship between the knowledge about HPV-related topics and the demographics, sexuality profile, and vaccination status of the participants. The test used assesses just a sample of declarative knowledge and not a deep understanding of HPV issues. Furthermore, since the study included medical students from a single school of medicine, it is impossible to generalize the findings to other schools or students.

Nevertheless, the results represent the student-body's grasp of HPV-related topics, and some findings show compelling associations. For example, we found it interesting that several students asked for more information about some test issues after the questionnaire application, even those already covered in the medical curriculum. The findings suggest a need for improvement in screening and vaccination programs and educational strategies regarding HPV-related diseases. Better instructional strategies may help future physicians to instruct different social groups and to clarify their patients' doubts about those topics.

\section{CONCLUSION}

The study revealed a strong correlation of medical students' HPV-related knowledge with the year attended at the medical school and significantly higher scores among sexually active and higher-income respondents, but no essential difference between males and females or between vaccinated and unvaccinated students. Altogether, the results indicate that the medical students' attributes and external backgrounds have a more considerable influence on the HPV-vaccination status than the educational environment and formal training.

\section{AUTHORS' CONTRIBUTION}

Miriam da Silva Wanderley: creation and supervision of the research project and study design, analysis and interpretation of data, writing of the original draft and review-editing of the manuscript. Dejano Tavares Sobral: creation of the research project and study design, statistical analysis and interpretation of data, writing of the original draft and review-editing of the manuscript. Ceres Nunes Resende: analysis and interpretation of data, writing of the final version of the manuscript, reviewediting of the manuscript. Lívia de Azevedo Levino, Luísa de Assis Marques, Mateus Silva Feijó, Nathália Regina Cardoso Aragão: field research, analysis and interpretation of data, writing and review-editing of the manuscript.

\section{CONFLICTS OF INTEREST}

The authors declare no conflicts of interest.

\section{SOURCES OF FUNDING}

The authors declare no sources of funding.

\section{REFERENCES}

1. Bray F, Ferlay J, Soerjomataram I, Siegel RL, Torre LA, Jemal A. Global cancer statistics 2018: GLOBOCAN estimates of incidence and mortality worldwide for 36 cancers in 185 countries. CA Cancer J Clin. 2018;68(6):394-424.

2. Brasil. Ministério da Saúde. Instituto Nacional de Câncer José Alencar Gomes da Silva. Incidência de Câncer no Brasil. Estimativa para 2020 [access in 04 feb 2020]. Available from: https://www.inca.gov.br/ estimativa/2020.pdf.

3. Hausen HZ. Papillomaviruses in the causation of human cancers - a brief historical account. Virology. 2009;384(2):260-5.

4. Muñoz N, Bosch FX, de Sanjosé S, Herrero R, Castellsagué X, Shah KV, et al International Agency for Research on Cancer Multicenter Cervical Cancer Study Group. Epidemiologic classification of human papillomavirus types associated with cervical cancer. N Engl J Med. 2003;348(6):518-27.

5. Wong LP. Preventing cervical cancer through human papillomavirus vaccination: perspective from focus groups. J Low Genit Tract Dis. 2009;13:85-93.

6. De Sanjose S, Quint WG, Alemany L, Geraets DT, Klaustermeier JE, Lloveras B, et al. Retrospective International Survey and HPV Time Trends Study Group. Human papillomavirus genotype attribution in invasive cervical cancer: a retrospective cross-sectional worldwide study. Lancet Oncol. 2010;11(11):1048-56.

7. Brasil. Ministério da Saúde. [access in 04 feb 2020].Available from: http:// portalms.saude.gov.br/images/pdf/2018/marco/14/Informe-T--clinicoHPV-MENINGITE.pdf.

8. Pan XF, Zhao ZM, Sun J, Chen F, Wen QL, Liu K, et al. Acceptability and correlates of primary and secondary prevention of cervical cancer among medical students in southwest China: implications for cancer education. PLoS One. 2014;9(10):e110353. 
9. Agorastos T, Chatzigeorgiou K, Brotherton JM, Garland SM. Safety of human papillomavirus (HPV) vaccines: a review of the international experience so far. Vaccine. 2009;27(52):7270-81.

10. Liu A, Ho FK, Chan LK, Ng JY, Li SL, Chan GC, et al. Chinese medical students' knowledge, attitude and practice towards human papillomavirus vaccination and their intention to recommend the vaccine. J Paediatr Child Health. 2018;54(3):302-10.

11. 11. Afonso NM, Kavanagh MJ, Swanberg SM, Schulte JM, Wunderlich T, Lucia VC. Will they lead by example? Assessment of vaccination rates and attitudes to human papillomavirus in millennial medical students. BMC Public Health. 2017;17(1):35.

12. McCusker SM, Macqueen I, Lough G, Macdonald Al, Campbell C, Graham SV. Gaps in detailed knowledge of human papillomavirus (HPV) and the HPV vaccine among medical students in Scotland. BMC Public Health. 2013;13:264.

13. Wen $Y$, Pan XF, Zhao ZM, Chen F, Fu CJ, Li SQ, et al. Knowledge of human papillomavirus (HPV) infection, cervical cancer, and HPV vaccine and its correlates among medical students in Southwest China: a multi-center cross-sectional survey. Asian Pac J Cancer Prev. 2014;15(14):5773-9.

14. Al-Shaikh GK, Almussaed EM, Fayed AA, Khan FH, Syed SB, Al-Tamimi TN, et al. Knowledge of Saudi female university students regarding cervical cancer and acceptance of the human papillomavirus vaccine. Saudi Med J. 2014;35(10):1223-30.

15. Ghojazadeh M, Azar ZF, Saleh P, Naghavi-Behzad M, Azar NG. Knowledge and attitude of Iranian University students toward human papillomavirus. Asian Pac J Cancer Prev. 2012;13(12):6115-9.

16. Deriemaeker $H$, Michielsen $D$, Reichman G, Devroey D, Cammu H. Knowledge about human papillomavirus and the human papillomavirus vaccine in Belgian students. CentEuropean J Urol. 2014;67(4):410-7.

17. Wanderley MS, Sobral, DT, Levino LA, Marques LA, Feijó MS, Aragão NRC. Students' HPV vaccination rates are associated with demographics, sexuality, and source of advice but not level of study in medical school. Rev Inst Med Trop São Paulo. 2019;61:e70.
18. Borlu A, Gunay O, Balci E, Sagiroglu M. Knowledge and Attitudes of Medical and Non-Medical Turkish University Students about Cervical Cancer and HPV Vaccination. Asian Pac J Cancer Prev. 2016;17(1):299-303.

19. Wong LP, Sam IC. Ethnically diverse female university students'knowledge and attitudes toward human papillomavirus (HPV), HPV vaccination and cervical cancer. Eur J Obstet Gynecol Reprod Biol, 2010;148:90-5.

20. Swarnapriya K, Kavitha D, Reddy GMM. Knowledge, Attitude and Practices Regarding HPV Vaccination Among Medical and Para Medical in Students, India a Cross-Sectional Study. Asian Pac J Cancer Prev 2015;16(18):8473-7.

21. Yam PW, Lam PL, Chan TK, Chau KW, Hsu ML, Lim YM, et al. A crosssectional study on knowledge, attitude and practice related to Human Papillomavirus vaccination for cervical cancer prevention between medical and non-medical students in Hong Kong, Asian Pac J Cancer Prev. 2017;18:1689-95.

22. Vatopoulou A, Papanikolaou A, Diavatis S, Goulis DG. Human Papilloma Virus Vaccination and Attitudes Towards Contraception: A Cross-Sectional Study. Eur J Contracept Reprod Health Care. 2019;24(3):182-7.

23. Mehta S, Rajaram S, Goel G, Goel N. Awareness about human papillomavirus and its vaccine among medical students. Indian J Community Med. 2013;38:92-4.

24. Perez S, Zimet GD, Tatar O, Stupiansky NW, Fisher WA, Rosberger Z. Human Papillomavirus Vaccines: Successes and Future Challenges. Drugs 2018;78(14):1385-96.

25. Ragin CC, Edwards RP, Jones J, Thurman NE, Hagan KL, Jones EA, et al. Knowledge about human papillomavirus and the HPV vaccine - a survey of the general population. Infect Agent Cancer. 2009;4(suppl 1):S10.

26. Forster AS, Marlow LAV, Stephenson J, Wardle J, Waller J. Human papillomavirus vaccination and sexual behaviour: cross-sectional and longitudinal surveys conducted in England. Vaccine.2012;30(33):4939-44.

27. Hansen T, Kjær K, Arnheim-Dahlström L, Liaw L, Jensen E, Thomsen T, et al. Human papillomavirus (HPV) vaccination and subsequent sexual behaviour: evidence from a large survey of Nordic women. Vaccine. 2014;32(39):4945-53. 